\title{
New and noteworthy records of lichens and allied fungi from Sakhalin Island, Russian Far East, II
}

\author{
Alexander K. Ezhkin ${ }^{1}$ \& Felix Schumm ${ }^{2}$ \\ ${ }^{1}$ Laboratory of Plant Ecology and Geoecology, Institute of Marine Geology and Geophysics, Far Eastern Branch Russian \\ Academy of Sciences, Nauki St., 1B, 693022 Yuzhno-Sakhalinsk, Russia. E-mail: ezhkin@yandex.ru \\ ${ }^{2}$ Mozartstraße 9, D-73117 Wangen, Germany. E-mail: fschumm@online.de
}

\begin{abstract}
Eopyrenula intermedia is a new finding for Eurasia. Fauriea orientochinensis and Hafellia subnexa are reported for the first time for Russia, from Sakhalin Island. A further seventeen species are noteworthy for Sakhalin Island, including two species new to the Russian Far East and five species new to the southern part of the region.
\end{abstract}

Keywords: biodiversity, Ascomycota, Asia, rare species

\section{INTRODUCTION}

Sakhalin Island is located in the northwestern part of the Pacific Ocean, north of Hokkaido, Japan. Its length is $948 \mathrm{~km}$ from $45^{\circ} 50$ ' $\mathrm{N}$ to $54^{\circ} 24^{\prime} \mathrm{N}$ with an area of $76,400 \mathrm{~km}^{2}$, and the maximum width of the island is $160 \mathrm{~km}$ (Kozynyuk, 1994). The climate is temperate monsoon type with a cold but milder winter than in the maritime part of the adjacent continent and with a cool rainy summer. The average temperature in January is $-6{ }^{\circ} \mathrm{C}$ (in the south) to $-22{ }^{\circ} \mathrm{C}$ (in the north), in August it is $18{ }^{\circ} \mathrm{C}$ and $10^{\circ} \mathrm{C}$, respectively. Precipitation ranges from $500 \mathrm{~mm}$ on the northwest coast, to $1200 \mathrm{~mm}$ in the mountainous regions and in the south (Zemtsova, 1968). Most parts of Sakhalin are covered by coniferous forests. The Sakhalin lichen biota is still poorly known and new records and noteworthy species continue to be discovered.

\section{MATERIAL AND METHODS}

This paper is based on the study of lichen collections from Sakhalin Island which were collected by the first author in the period 2012-2017. Examined specimens are deposited in the herbaria of Institute of Marine Geology and Geophysics (SAK). All the material was examined using standard microscopic techniques with light microscopes MBS-10 and LOMO Mikmed 3. Secondary metabolites were identified by high performance thin-layer chromatography (HPTLC) according to the methods described in Schumm \& Elix (2015). Spot tests were made with $10 \% \mathrm{KOH}(\mathrm{K}), \mathrm{Ca}(\mathrm{ClO})_{2}(\mathrm{C})$ and $\left[\mathrm{C}_{6} \mathrm{H}_{4}\left(\mathrm{NH}_{2}\right)_{2}\right]$
(P). Photos of lichen specimens were made using microscope Axio Scope A1 Carl Zeiss and microtome Thermo Scientific Microm HI 1430. The following signs are used in the species list: ! - species new to Eurasia, !! - species new to Russia, !!! - species new to the Russian Far East.

\section{THE SPECIES}

!!!ACROCORdiA CAVATA (Ach.) R.C. Harris

The species is similar to Acrocordia gemmata (Ach.) A. Massal. but with smaller perithecia and ascospores. A. cavata is a corticolous species known from Europe, North America and Asian part of Russia (Smith et al., 2009; Urbanavichus, 2010). The species is reported for the first time from the Russian Far East.

Specimen examined: Yuzhno-Sakhalinsk City surroundings, Rogatka River valley, 46 $58^{\prime} 5.707^{\prime \prime}$, $142^{\circ} 47^{\prime} 4.03$ " E, alt. $162 \mathrm{~m}$, streamside forest, on bark of Salix udensis Trautv., 20 November 2016, leg. A. K. Ezhkin (SAK 698), det. L. Konoreva.

ARthothelium Ruanum (A. Massal.) Körb

The species is close to Arthothelium spectabile A. Massal. from which it can be distinguished by more closely spaced asci, arranged in more or less distinct groups (Grube \& Giralt, 1996). A. ruanum is a corticolous species, which occurs on smooth bark of deciduous trees. The species is widespread in Europe, North America and Asia (Smith et al., 2009) and is known from several regions of the Russian Far East (Tchabanenko, 2002). The species is new for Sakhalin.

Specimen examined: Yuzhno-Sakhalinsk City surroundings, Rogatka River valley, 4658'5.707”N, 
$142^{\circ} 47^{\prime} 49.03$ ” E, alt. $162 \mathrm{~m}$, streamside forest, on bark of Alnus hirsuta (Spach.) Rupr., 20 November 2016 leg. A. K. Ezhkin (SAK 695), det. L. Konoreva.

BRYOBILIMBIA HYPNORUM (Lib.) Fryday et al. This species is characterized by greenish epihymenium and colourless hymenium. It is a cool-temperate to arctic-alpine lichen growing on bryophytes or plant debris, on calcareous soil and occasionally on old tree trunks (Hawksworth $\&$ Coppins, 1992; Beauchamp et al., 2007). The species is known from Europe, Macaronesia, North America, Asia, Africa, Subantarctic Islands (Smith et al., 2009). It is widespread in Russia, including the Far East (Urbanavichus, 2010), and is new for Sakhalin.

Specimen examined: Chehovskiy district, Arkansas River valley, $47^{\circ} 31^{\prime} 16.5^{\prime \prime} \mathrm{N}, 141^{\circ} 59^{\prime} 01.9 " \mathrm{E}$, alt. $83 \mathrm{~m}$, streamside forest, on bark of Phellodendron sakhalinense (F. Schmidt) Sarg., 29 June 2016, A. K. Ezhkin (SAK 1326), det. L. Konoreva.

\section{Calicium salicinum Pers.}

The species is characterized by spirally ornamented spores, brown pruina on the lower side of the excipulum that are $\mathrm{K}+$. The species is widely distributed in cool to temperate areas of Europe, Macaronesia, North and South America, Asia, Africa, Australia, New Zealand (Ahti et al., 1999; Smith et al., 2009). It has been reported from the southern Russian Far East, from the Primorsky and Khabarovsky regions, and the Kunashir Island (Tchabanenko, 2002). The species is new for Sakhalin.

Specimen examined: Dolinskiy district, the Pchelinaya River valley, $47^{\circ} 22$ '18.53”N, $142^{\circ} 53^{\prime} 0.3$ 'E, alt. 22 $\mathrm{m}$, streamside forest, on dead twig of Sambucus sp., 5 November 2012, A. K. Ezhkin (SAK 646).

Caloplaca scotoplaca (Nyl.) Magn.

The species belongs to Caloplaca ferruginea group, characterized by greyish-black areoles and abundant reddish-orange apothecia. It is distinguished from the similar $C$. crenularia (With.) Laundon by its black pycnidia, and smaller apothecia and spores. C. scotoplaca is widespread saxicolous lichen known from Europe, Asia and North America (Andreev et al., 1996; Khodosovtsev et al., 2004). It is widespread in Russia including the northern part of the Far East (Urbanavichus, 2010). The species is a new record for Sakhalin Island and the southern part of the Russsian Far East.

Specimen examined: Yuzhno-Sakhalinsk City surroundings, Mt. Chehova, Voroniy Kamen', 4659'08.13”N, 14249'42.91"E, alt. $660 \mathrm{~m}$, mixed forest, on rocks, 13 September 2012, leg. A. K. Ezhkin (SAK 1325), det. S. Chesnokov.

Collema Japonicum (Müll. Arg.) Hue

The species is characterized by its smooth thallus, lack of isidia, non-pruinose apothecia, corticate excipulum thallinum, usually euparaplectenchymatous excipulum proprium, and large fusiform 6-celled spores. It is similar to the isidiate C. flaccidum (Ach.) Ach. Collema. japonicum is a mainly corticolous species known from Eastern Asia, Australia and Oceania (Degelius, 1974). In Russia it is known from the Kunashir Island and Primorskiy region (Makryi \& Skirina, 2009). The species is new for Sakhalin.

Specimen examined: Yuzhno-Sakhalinsk City surroundings, Mitsulskiy Range, Mt. Mitsul, western slope, 4703'02.2932"N, 142 ${ }^{\circ} 30$ '39.4704"E, alt. 536 $\mathrm{m}$, mixed forest, on bark old Salix caprea L., 20 May 2017, leg. A. K. Ezhkin (SAK109).

Diploschistes muscorum (Scop.) R. Sant.

The species is characterized by 4-spored asci and ascospores with 5 transverse and 1-2 longitudinal septa. It is a cosmopolitan species (Hawksworth, 1983), widespread in Russia including the Far East, Kamchatka and Primorskiy regions (Skirina, 1995; Urbanavichus, 2010; Neshataeva et al., 2014). The species is new for Sakhalin.

Specimen examined: Yuzhno-Sakhalinsk City surroundings, Susunaiskiy Range, Mt. Vorobyinaya, $46^{\circ} 58^{\prime} 34.4^{\prime \prime} \mathrm{N}, 142^{\circ} 48^{\prime} 25.1^{\prime} \mathrm{E}$, alt. $448 \mathrm{~m}$, managed dark conifer forest, on mossy rock, 03 September 2016, leg. A. K. Ezhkin (SAK 571).

!EOPYREnUla INTERMEdia Coppins (Fig. 1)

Thallus white, matt, cortex absent, not lichenized (no photobiont seen), UV- (bluewhite); perithecium dimidiate; hymenium $\mathrm{J}+$ red-brown, not inspersed, paraphyses not branched; asci I- (not blue); ascospores brown, 3-5 septate, $15-22 \times 7 \mu \mathrm{m}$, lacking special thickened walls, $8 /$ ascus. The species is corticolous, previously known only from the temperate zone of North America (Aptroot, 2012). It is distinguished from the related species E. leucoplaca (Wallr.) R.C. Harris in its ascocarp characters, by a larger proportion of 3-septate ascospores and by the size of macroconidia and number of septa (Aptroot, 2012). E. intermedia is reported for the first time from Eurasia.

Specimens examined: Yuzhno-Sakhalinsk City surroundings, Rogatka River valley, 46 $58^{\prime} 00.4^{\prime \prime N}$, $142^{\circ} 46^{\prime} 13.0$ 'E, alt. $111 \mathrm{~m}$, floodplain forest, on bark of Populus maximowiczii Henry., 04 May 2015, leg. A. K. Ezhkin (SAK 135), det. A. Aptroot. 


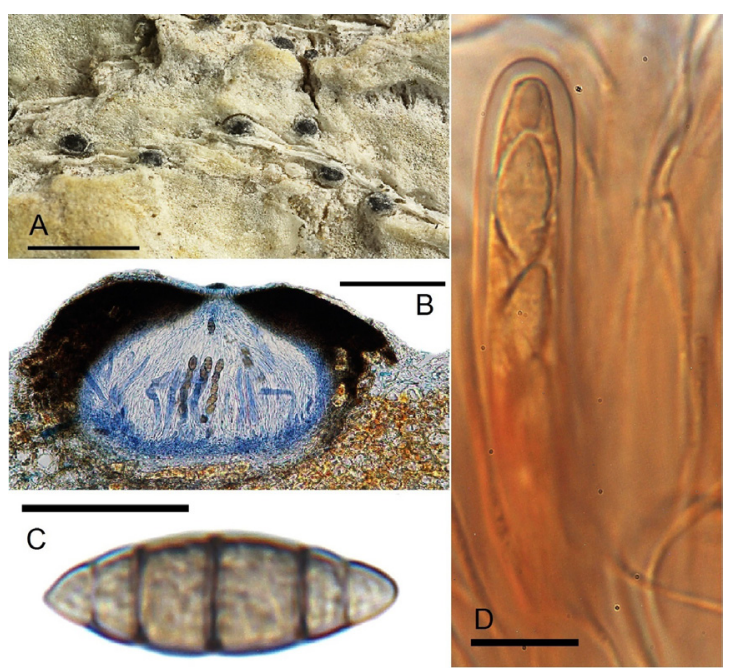

Fig. 1. Eopyrenula intermedia (SAK 135). A thallus with apothecia; $\mathrm{B}$ - apothecium in cross section; $\mathrm{C}$ - an ascospore; $\mathrm{D}$ - asci with spores in $\mathrm{K}, \mathrm{K}+$ red/brown. Scale bars: $\mathrm{A}=1 \mathrm{~mm}$; $\mathrm{B}=$ $100 \mu \mathrm{m} ; \mathrm{C}$ and $\mathrm{D}=10 \mu \mathrm{m}$.

!!FAURIEA ORIENTOCHINENSIS S.Y. Kondr., X.Y. Wang \& J.-S. Hur

The species is characterized by a whitish-grey, crustose thallus with lecanorine apothecia possessing dull, dark violet-brown discs and widely ellipsoid, colourless, 1 -septate ascospores. This is a rare corticolous species known only the eastern part of China from where it was described (Kondratyuk et al., 2016). It is reported for the first time from Russia.

Specimen examined: Tunaicha Lake surroundings, Korsakovskiy district, $46^{\circ} 48^{\prime} 07.4^{\prime \prime} \mathrm{N}, 143^{\circ} 06^{\prime} 15.7^{\prime} \mathrm{E}$, alt. $0 \mathrm{~m}$, mixed forest, on bark of Populus maximowiczii Henry., 26 October 2017, leg. A. K. Ezhkin (SAK 1285), det. J. Vondrak.

!!Hafellia subnexa (Nyl.) Marbach (Fig. 2)

Thallus areolate, crustose, to $2 \mathrm{~cm}$ in diam., with black apothecia 0.3-0.9 $\mathrm{mm}$ in diam.; hypothecium and excipulum proprium brownish-black; hymenium colourless, densely inspersed with oil; tips of paraphyses not, or nearly not, swollen without pigmented caps; ascospores brown, 1 -septate, 16 per ascus, (13)15-16 × 6-7 $\mu \mathrm{m}$. The chemistry of the species differs from the original description as our material contains fumarprotocetraric (major) and protocetraric acids, norstictic acid being absent. This species is close to the 16-spored H. pleiotera Malme which has positive reaction of epihymenium (KOH+ violet) (Marbach, 2000). Hafellia subnexa is a corticolous species with a tropical and subtropical distribution. Previously known from Japan and Malaysia, it is reported for the first time from Russia.

Specimen examined: The Cape of Slepikovskogo, Kholmskiy district, $47^{\circ} 17^{\prime} 21.0^{\prime \prime} \mathrm{N} 141^{\circ} 58^{\prime} 56.4^{\prime} \mathrm{E}$, alt. $12 \mathrm{~m}$, oak forest, on bark of Quersus crispula Blume, 18 May 2013, leg. A. K. Ezhkin (SAK 121).

IONASPIS OBTECTA (Vain.) R. Sant.

The species is characterized by a crackedareolate thallus, sessile apothecia with proper, thick margins, pale red concave discs, and a $\mathrm{K}^{+}$ yellow hymenium. It is saxicolous lichen known from Europe and Asian part of Russia including the northern part of the Far East (Smith et al., 2009; Urbanavichus, 2010). The species is reported for the first time from the southern part of the Russian Far East and Sakhalin.

Specimen examined: Yuzhno-Sakhalinsk City surroundings, Mt. Chehova, $47^{\circ} 00.490 ’ \mathrm{~N}, 142^{\circ} 48.250$ 'E, alt. $1045 \mathrm{~m}$, alpine vegetation, on rocks, 13 September 2012, leg. A. K. Ezhkin (SAK 1324, 1329), det. S. Chesnokov.

LECANORA INTRICATA (Ach.) Ach.

The species belongs to Lecanora polytropa group. It is distinguished from the more common $L$. polytropa (Ehrh. ex Hoffm.) Rabenh. by the indented margins of the more strongly emergent areoles and immersed apothecia with darker discs. The species is a widespread saxicolous lichen, probably cosmopolitan (Smith et al., 2009), known from several regions of Russia including the northern part of the Russian Far

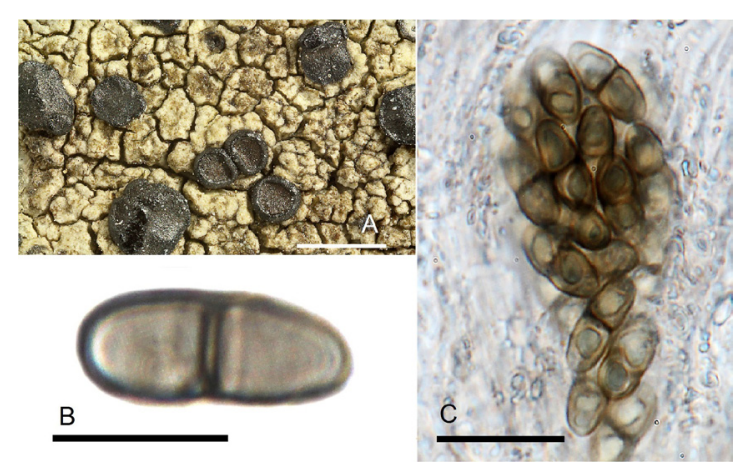

Fig. 2. Hafellia subnexa (SAK 121). A - thallus with apothecia; $\mathrm{B}$ - an ascospore; $\mathrm{C}$ - asci with 16 spores. Scale bars: $A=1 \mathrm{~mm} ; B=10 \mu \mathrm{m}$; $\mathrm{C}=20 \mu \mathrm{m}$. 
East (Andreev et al., 1996; Himelbrant et al., 2009). It is a new record for Sakhalin and the southern part of the Russsian Far East.

Specimen examined: Yuzhno-Sakhalinsk City surroundings, Mt. Chehova, $47^{\circ} 00.490^{\prime} \mathrm{N}, 142^{\circ} 48.250^{\prime} \mathrm{E}$, alt. $1045 \mathrm{~m}$, alpine vegetation, on rocks, 13 September 2012, leg. A. K. Ezhkin (SAK 1317), det. S. Chesnokov.

LECIDEA SWARTZIOIDEA Nyl.

The species belongs to Lecidea lapicida group and is characterized by a well developed epilithic thallus, blackish-brown hypothecia and $\mathrm{K}+\mathrm{red}$, I- reactions of the medulla. It is a widespread, being known from Great Britain, Europe, North America, Novaya Zemlya, Kamchatka, Siberia (Smith et al., 2009; Andreev et al., 1996; Urbanavichus, 2010). The species is a new record for Sakhalin and the southern part of the Russsian Far East.

Specimen examined: Yuzhno-Sakhalinsk City surroundings, Mt. Chehova, $47^{\circ} 00.490^{\prime} \mathrm{N}, 142^{\circ} 48.250^{\prime} \mathrm{E}$, alt. $1045 \mathrm{~m}$, alpine vegetation, on rocks, 13 September 2012, leg. A. K. Ezhkin (SAK 1319), det. S. Chesnokov.

\section{!!!LithOGRAPHA TESSERATA (DC.) Nyl.}

The species is characterized by pale grey-brown, strongly areolate thallus, crowded, shortly lirellate apothecia, simple spores and $\mathrm{K}+$ red, $\mathrm{Pd}+$ orange reactions of medulla. The species is a widespread saxicolous lichen, known from Europe, Asia, North America (Smith et al., 2009; Sedelnikova, 2013) and is a new record for Sakhalin and the Russian Far East.

Specimen examined: Yuzhno-Sakhalinsk City surroundings, Mt. Chehova, $47^{\circ} 00.490^{\prime} \mathrm{N}, 142^{\circ} 48.250^{\prime} \mathrm{E}$, alt. $1045 \mathrm{~m}$, alpine vegetation, on rocks, 13 September 2012, leg. A. K. Ezhkin (SAK 1322), det. S. Chesnokov.

LOBARIA GYROPHORICA Yoshim.

The species is characterized by its foliose greenish- to yellowish-brown thallus. Its upper surface is more or less ridged, without soredia, isidia or lobules, and the lower surface is light yellow-brown, ridged, covered with brown rhizines and tomentum. Spot tests: upper cortex: $\mathrm{K}-, \mathrm{PD}-, \mathrm{C}-, \mathrm{KC}-$; medulla: $\mathrm{K}-, \mathrm{PD}-, \mathrm{C}+$ reddish pink, containing gyrophoric acid (HPTLC). The species is close to Lobaria orientalis (Asahina) Yoshim., but it does not contain norstictic and stictic acids. It is a corticolous species found mainly in temperate zone on deciduous trees, previously known from Japan, Taiwan and China (Yoshimura, 1971). In Russia, it is known only from Shikotan Island (South Kuriles) (Chabanenko, 2014), and is new for Sakhalin. Specimen examined: Korsakovskiy district, Prig- orodnoye Village surroundings, $46^{\circ} 38^{\prime} 36.50^{\prime \prime} \mathrm{N}$ $142^{\circ} 54^{\prime} 10.27^{\prime \prime} \mathrm{E}$, alt. $13 \mathrm{~m}$, dark coniferous forest, on bark of Picea jezoensis (Sieb. et Juss.) Carr., 07 July 2014, leg. A. K. Ezhkin (SAK 619).

NipPONOPARMELIA PERPLICATA S.Y. Kondr., Tschab., Elix \& Hur

The species is characterized by irregular lobes with down-turned lobe ends, inconspicuous pseudocyphellae seen mainly on the underside, and by the lack of marginal lobules or isidia. It is a rare corticolous species known from scattered localities in Korea and Shikotan Island (Kondratyk at al., 2013). This is a new species for Sakhalin.

Specimen examined: Nevelskiy district, Lovetskiy

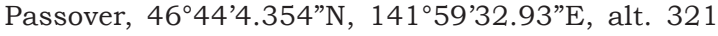
$\mathrm{m}$, mixed forest, on bark of Abies sakhalinensis $\mathrm{F}$. Schmidt, 11 June 2013, leg. A. K. Ezhkin (SAK 108).

RHIZOCARPON CINEREOVIRENS (Müll. Arg.) Vain. The species is characterized by a rough, verrucose, areolate, gray thallus, colourless 1-septate spores, and $\mathrm{K}+\mathrm{red}, \mathrm{Pd}+$ orange reactions of medulla. The species is a widespread saxicolous lichen known from northern and central Europe, North America and Asia including the Arctic part of Far East Russia (Smith et al., 2009; Andreev et al., 1996; Urbanavichus, 2010). The species has been reported from the southern part of the Russian Far East, Khabarovskiy district (Randlane, 1984). The species is a new record for Sakhalin Island.

Specimens examined: Yuzhno-Sakhalinsk City surroundings, Mt. Chehova, $47^{\circ} 00.490^{\prime} \mathrm{N}, 142^{\circ} 48.250^{\prime} \mathrm{E}$, alt. $1045 \mathrm{~m}$, alpine vegetation, on rocks, 13 September 2012, leg. A. K. Ezhkin (SAK 1326, 1327, 1328), det. S. Chesnokov.

RHIZOCARPON REDUCTUM Th. Fr.

The species is distinguished by its small, cracked-areolate thallus $1-2 \mathrm{~cm}$ in diam., small colourless, eumuriform ascospores and usually $\mathrm{K}+$ yellow, $\mathrm{Pd}+$ orange reactions of the thallus. It is the commonest non-yellow Rhizocarpon species which occurs early in the succession on newly exposed siliceous rocks (Fryday, 2000; Smith et al., 2009). It is cosmopolitan and widespread in Russia (Andreev et al., 1996; Urbanavichus, 2010), known from the southern part of the Russian Far East, Khabarovskiy District (Randlane, 1984). This is a new species for Sakhalin.

Specimen examined: Yuzhno-Sakhalinsk City surroundings, Mt. Chehova, $47^{\circ} 00.490^{\prime} \mathrm{N}, 142^{\circ} 48.250^{\prime} \mathrm{E}$, alt. $1045 \mathrm{~m}$, alpine vegetation, on rocks, 13 September, 2012, leg. A. K. Ezhkin (SAK 1321), det. S. Chesnokov. 
Ropalospora LUgubris (Sommerf.) Poelt

The species is characterized by a brownish-gray thallus with dark prothallus and black apothecia, and iusually esorediate but occasionally possesses a few distinct soralia. Its spores are transversely 5-7-septate, often curved and narrowly pointed at one end. Sorediate forms of $R$. lugubris are similar to R. atroumbrina $(\mathrm{H}$. Magn.) S. Ekman but can be distinguished by their soralia which are few, well delimited and farinose. Ropalspora lugubris is a saxicolous species known from Europe, Asia, Africa, North America, Tasmania (Ekman, 1994; Urbanavichus, 2010). It is also reported from the southern part of the Russian Far East, Primorskiy and Khabarovskiy Districts (Tchabanenko, 2002). This is a new species for Sakhalin.

Specimen examined: Yuzhno-Sakhalinsk City surroundings, Mt. Chehova, $47^{\circ} 00.490^{\prime} \mathrm{N}, 142^{\circ} 48.250^{\prime} \mathrm{E}$, alt. $1045 \mathrm{~m}$, alpine vegetation, on rocks, 13 September 2012, leg. A. K. Ezhkin (SAK 1314), det. S. Chesnokov.

SchaERERIA FUscocinerea (Nyl.) Clauzade \& $\mathrm{Cl}$. Roux

The species is characterized by grayish, dark blue or blackish brown thallus with immersed apothecia often having a false thalline margin of Aspicilia-like appearance and is often associated with yellow Rhizocarpon species. It is a saxicolous, bipolar, widespread lichen (Hertel $\&$ Andreev, 2003). In Russia this species is reported from Beringian Chukotka by Nylander (1888) and Vainio (1909). The species is a new record for Sakhalin and the southern part of the Russian Far East.

Specimen examined: Yuzhno-Sakhalinsk City surroundings, Mt. Chehova, $47^{\circ} 00.490^{\prime} \mathrm{N}, 142^{\circ} 48.250^{\prime} \mathrm{E}$, alt. $1045 \mathrm{~m}$, alpine vegetation, on rocks, 13 September 2012, leg. A. K. Ezhkin (SAK 1315), det. S. Chesnokov.

\section{ACKNOWLEDGEMENTS}

We are grateful to Sergey Chesnokov, Lyudmila Konoreva, Andre Aptroot and Jan Vondrak for determination of some taxa. Special thanks to John Sheard for linguistic assistance and text corrections. The study was financially supported by the Russian Foundation for Basic Research (Grants No. 18-04-00098\18) and Global Green Grants Fund.

\section{REFERENCES}

Ahti, T., Jørgensen, P. M., Kristinsson, H., Moberg, R., Søchting, U., \& Thor, G. 1999. Nordic Lichen Flora.
Vol. 1. Introductory parts. Calicioid lichens and fungi. Nordic Lichen Society. Uddevalla. 94 pp.

Andreev, M., Kotlov, Y., \& Makarova, I. 1996. Checklist of lichens and lichenicolous fungi of the Russian Arctic. The Bryologist 99(2): 137-169. https:// doi.org/ 10.2307/3244545

Aptroot, A. 2012. A world key to the species of Anthracothecium and Pyrenula. The Lichenologist 44(1): 5-53. https://doi.org/10.1017/ S0024282911000624

Beauchamp, H., Vust, M., \& Clerc, P. 2007. Notes on selected terricolous crustaceous lichens of Switzerland: distributional, ecological and red list data. Herzogia 20: 115-144.

Chabanenko, S. I. 2014. To studying of lichens of the Island Shikotan (Sakhalin Region). In: The Vegetation of North Eastern Asia. (In Russian). Materials of Science Conference, Bryansk. GUP, Bryansk Polygraphic Association. Pp. 152-153.

Degelius, G. 1974. Lichen genus Collema with special reference to the extra-European species. Symbolae Botanicae Upsalienses. 215 pp.

Ekman, S. 1993. A taxonomic study of Ropalospora chlorantha, and a comparison between Ropalospora and Fuscidea. The Bryologist 96(4): 582-591. https://doi.org/10.2307/3243989

Fryday, A. 2000. On Rhizocarpon obscuratum (Ach.) Massal., with notes on some related species in the British Isles. The Lichenologist 32(3): 207-224. https://doi.org/10.1006/lich.2000.0269

Hawksworth, D. L. 1983. A key to the lichen-forming, parasitic, parasymbiotic and saprophytic fungi occurring on lichens in the British Isles. The Lichenologist 15(1): 1-44. https://doi.org/10.1017/ S0024282983000031

Hawksworth, D. L. \& Coppins, B. J. 1992. Lecidea Ach. (1803). In: Smith, C. W., Aptroot, A., Coppins, B. J., Fletcher, A., Gilbert, O. L., James P. W. \& Wolseley, P. A. (eds) The lichen flora of Great Britain and Ireland. British Lichen Society. London Pp. 318-336.

Hertel, H. \& Andreev, M. P. 2003. On some saxicolous lecideoid lichens of the Beringian region and adjacent areas of eastern Siberia and the Russian Far East. The Bryologist 106(4): 539-551. https:/ / doi.org/10.1639/0007-2745(2003)106[539:OSS LLO]2.0.CO;2

Himelbrant, D. E., Stepanchikova, I. S. \& Kuznetsova, E. S. 2009. Lichens of some shrubs and dwarf shrubs of Kamchatka Peninsula. (In Russian). Novitates Systematicae Plantarum Non Vascularum 43: 150-171.

Grube, M. \& Giralt, M. 1996. Studies on some species of Arthothelium occurring in the western Mediterranean. The Lichenologist 28(1): 15-36. https:// doi.org/10.1006/lich.1996.0003

Khodosovtsev, A. Y., Kondratyuk, S. Y., Makarova, I. I. \& Oxner, A. N. 2004. Handbook of the lichens of Russia. 9. Fuscideaceae, Teloschistaceae. (in Russian). Russian Academy of Sciences. St. Petersburg. 340 pp. 
Kondratyuk, S., Elix, J., Galanina, I., Yakovchenko, L., Kärnefelt, I. \& Thell, A. 2011. Four new Caloplaca species (Teloschistaceae, Ascomycotina). Folia Cryptogamica Estonica 48: 17-23.

Kondratyuk, S. Y., Lökös, L., Kim, J. A., Kondratiuk, A. S., Jeong, M. H., Jang, S. H., Oh, S. O., Wang X. Y. \& Hur, J. S. 2016. Fauriea, a new genus of the lecanoroid caloplacoid lichens (Teloschistaceae, lichen-forming ascomycetes). Acta Botanica Hungarica 58(3-4): 303-318. https://doi.org/10.1556/ ABot.58.2016.3-4.6

Kondratyuk, S. Y., Tschabanenko, S. I., Elix, J. A., Oh, S. O., Thell, A., \& Hur, J. S. 2014. Nipponoparmelia perplicata sp. nov. (Parmeliaceae, Ascomycota) from eastern Asia. Mycotaxon 126(1): 37-44. https: / / doi.org/ 10.5248/126.37

Kozynyuk, V. M. 1994. Atlas of the Sakhalin Region. (In Russian). Resources and Economics. YuzhnoSakhalinsk. 21 pp.

Kurokawa, S. 1962. A monograph of the genus Anaptychia. Beihefte zur Nova Hedwigia 6: 1-115.

Makryi, T. V. \& Skirina, I. F. 2009. Rare and poorly studied in Russia epiphytic species of Collema (Collemataceae, Lichenes) from south part of Far East. (In Russian). Turczaninowia 12(3-4): 53-62.

Marbach, B. 2000. Corticole und lignicole Arten der Flechtengattung Buellia-sensu lato in den Subtropen und Tropen. Bibliotheca Lichenologica 74: 1-384.

Mongkolsuk, P., Meesim, S., Poengsungnoen, V., Buaruang, K., Schumm, F. \& Kalb, K. 2015. The lichen family Physciaceae in ThailandII. Contributions to the genus Heterodermia sensu lato. Phytotaxa 235(1): 1-66. https://doi. org/10.11646/phytotaxa.235.1.1
Neshataeva, V. Yu., Korablev, A. P., Vyatkina, M. P., \& Neshataev, V. Yu. 2014. Vegetation of volcanic plato of Central Kamchatka. (In Russian). KMK. Moscow. Pp. 165-230.

Randlane, T. V. 1984. About lichens of goltsy altitudinal belt (Khabarovskiy district). In: Flora and groups of inferior plants in nature and anthropogenic extreme environmental conditions. Tallinn. Pp. 120-133.

Sedelnikova, N. V. 2013. Lichen species diversity of Altai-Sayanskiy district. (In Russian). In: Rastitelnyj mir Aziatskoj Rossii. Bulletin of Central Siberian Botanical Garden, SB RAS 2(12): 12-54.

Schumm, F. \& Elix, J. A. 2015. Atlas of images of thin layer chromatograms of lichen substances. Books on Demand GmbH. Norderstedt. 578 pp.

Skirina, I. F. 2015. Lichens Sikhote-Alin biosphere district. (In Russian). Biodiversity and Environment of Far East Reserve 3: 10-102 pp.

Smith, C. W., Aptroot, A., Coppins, B. J., Fletcher, A., Gilbert, O. L., James P. W. \& Wolseley, P. A. (eds) 2009. Lichens of Great Britain and Ireland. The British Lichen Society. London. 1046 pp.

Tchabanenko, S. I. 2002. Synopsis of lichen flora of the South of the Russian Far East. (In Russian). Dal'nauka. Vladivostok. $232 \mathrm{pp}$.

Urbanavichus, G. P. (comp.) 2010. A checklist of the lichen flora of Russia. (In Russian). Nauka. St.Petersburg. 194 pp.

Yoshimura, I. 1971. Genus Lobaria of Eastern Asia. The Journal of the Hattori Botanical Laboratory 34: 231-364.

Zemtsova, A. I. 1968. The Climate of Sakhalin Island. (In Russian). Nauka. Leningrad. 197 pp. 